\title{
The cavity electrocardiogram in emergency artificial pacing
}

\author{
K. ChatterjeE* \\ M.B.(Cal.), M.R.C.P., M.R.C.P.E. \\ Registrar \\ C. A. Layton $\ddagger$ \\ M.B.(Lond.)
}

\author{
Richard SutTon $\dagger$ \\ M.B.(Lond.), M.R.C.P. \\ Research Fellow
}

ANN EDWARDS

Cardiac Technician

House Surgeon

\author{
Cardiac Department, \\ St George's Hospital, London, S.W.1
}

\section{Summary}

Effective temporary pacing was achieved using the cavity ECG as a guide in twenty-five of twenty-six patients, twenty of whom were too ill to be moved to the fluoroscope.

In all patients U.S.C.I. unipolar or bipolar electrodes were used and in eleven patients this method of pacing was applied during resuscitation; four patients survived to leave hospital.

This technique is described and is recommended for emergency pacing when a bedside image intensifier is unavailable.

\section{Introduction}

Endocardial pacing is now a well established method of treatment of both acute and chronic heart block. For long-term pacing, fluoroscopic control is essential to position the electrode tip accurately in the apex of the right ventricle. For emergency pacing, however, an electrode can be inserted rapidly using the cavity electrocardiogram (ECG) recorded from the electrode tip. The technique, which has been used in some centres for a number of years (Harris et al., 1965; Kimball \& Killip, 1965; Bay \& Sivertssen, 1967), and its application are described in this communication; it has proved invaluable in approximately $5 \%$ of patients admitted to our pacing unit.

\section{Method}

Unipolar C.50\$ or bipolar C.51-52\$ electrodes were used in twenty-six patients and were inserted from medial antecubital veins in twenty-two, cephalic

*Present address: Cardiac Laboratory, The Brompton Hospital, London, S.W.3.

†Present address: Cardiac Laboratory, North Carolina Memorial Hospital, Chapel Hill, North Carolina, U.S.A.

‡Present address: Neurology Unit, Atkinson Morley's Hospital, London, S.W.20.

§ U.S.C.I. recatalogued 5650, 5651, 5652 veins in two, right subclavian vein in one and right external jugular vein in one patient. The veins were approached either percutaneously using a large 'intracath' needle, or by direct 'cutdown'. All four limb leads of a battery-powered electrocardiograph were attached to the patient and the chest lead switched to ' $\mathrm{V}$ ' was connected to the free end of the electrode. The pacing electrode was then advanced and the cavity ECG, recorded from the tip of the electrode, was monitored continuously. As soon as the characteristic pattern of the right atrium was observed, the electrode was advanced more slowly, and with slight manipulation (advancing and twisting simultaneously), the tip passed through the tricuspid valve, as shown by the change in the cavity ECG to ventricular pattern (Fig. 1). The electrode was advanced gradually until S-T elevation was observed, indicating contact of the tip with ventricular endocardium. When a unipolar electrode was used, a stainless steel indifferent electrode was inserted subcutaneously through the original incision. The pacemaker was connected and the threshold measured, and if greater than $1 \mathrm{~V}$ at a pulse width of $2 \mathrm{~m}-\mathrm{sec}$, and provided the clinical condition of the patient permitted, the electrode was re-positioned. Later the electrode position was checked with a portable X-ray. Demand pacemakers (ventricular inhibited pacemakers) were used in all patients. At each procedure a DC defibrillator and an external stimulator were immediately available and an intravenous infusion was set up to facilitate the rapid administration of drugs. The whole procedure was completed in less than $10 \mathrm{~min}$ in almost all patients.

\section{Results}

The technique has been used in twenty-six patients, who have been divided into three groups (Table 1) according to their indications for pacing. 


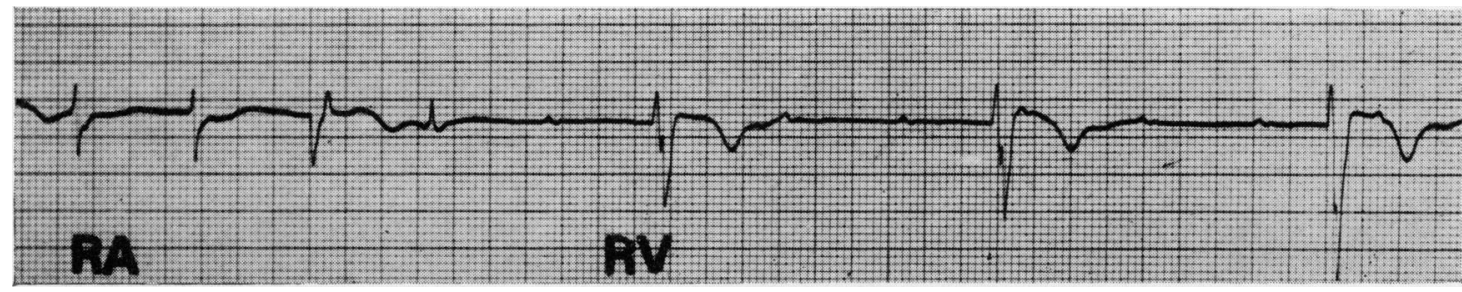

FIG. 1. Cavity ECG recorded from electrode passing from right atrium to right ventricle.

TABLE 1.

\begin{tabular}{clcc}
\hline Group & $\begin{array}{c}\text { Indications for pacing } \\
\text { using cavity ECG }\end{array}$ & No. of patients & Survivors \\
\hline A & $\begin{array}{l}\text { During resuscitation } \\
\text { from cardiac arrest }\end{array}$ & 11 & 4 \\
B & $\begin{array}{l}\text { Too ill to be moved } \\
\text { C }\end{array}$ & 9 & 5 \\
& $\begin{array}{l}\text { Image intensifier not } \\
\text { available }\end{array}$ & 6 & 6 \\
\hline
\end{tabular}

\section{Group $A$}

In eleven patients, electrode insertion was carried out during resuscitation from ventricular fibrillation or arrest. Four of them survived to leave hospital. Immediate pacing was achieved in all but one. A brief history of each patient is given in Table 2.

\section{Group B}

Nine patients were considered too ill to be moved to the X-ray Department for the use of fluoroscopy for electrode insertion. Four had had recent myocardial infarction complicated by second degree or complete A-V block, three with chronic heart block had recurrent Adams-Stokes attacks and acute left ventricular failure, one had Adams-Stokes attacks and complete heart block which developed after mitral valve replacement, and one had sinus arrest with recurrent syncope following pneumonectomy. Five of these patients survived.

\section{Group C}

In six patients electrodes were inserted by this technique because, for various reasons, the image intensifier was not available. Four had acute heart block complicating myocardial infarction and two were paced temporarily before installation of a permanent system. None of these patients was acutely ill and all survived.

\section{Complications}

Obstruction to the passage of the electrode, especially when a median cubital arm vein was used, occurred in a few patients but was easily overcome by abduction and rotation of the arm. On two occasions the electrode formed a 'knot' in the right atrium; both patients had to be transferred to the $\mathrm{X}$-ray Department to uncoil the knots.

A series of ventricular ectopics was frequently observed when the electrode tip crossed the tricuspid valve, but these progressed to ventricular fibrillation in only one patient, who was resuscitated successfully (Fig. 2).

The myocardium was not perforated by the electrode tip at insertion in any of these patients, but one perforation occurred after 3 days, necessitating electrode repositioning. Electrode displacements, also requiring repositioning, occurred in six patients but none suffered any ill effects.

Pacing was unsuccessful in only one patient, who had both atrial and ventricular asystole so that the position of the electrode tip could not be ascertained.

\section{Discussion}

For long-term endocardial pacing, fluoroscopic control using a high definition image intensifier is

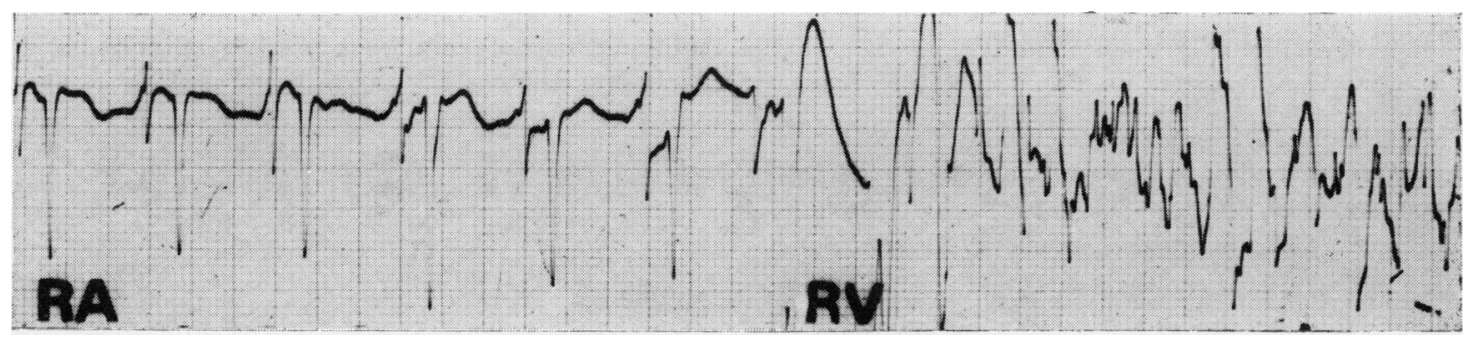

FIG. 2. Cavity ECG from electrode passing from right atrium to right ventricle. One normal ventricular complex is followed by ventricular fibrillation. 
TABLE 2

\begin{tabular}{|c|c|c|c|}
\hline Case No. & Indication for pacing & Diagnosis & Outcome \\
\hline 1 & $\begin{array}{l}\text { Complete heart block. } \\
\text { Recurrent ventricular } \\
\text { asystole }\end{array}$ & $\begin{array}{l}\text { Acute myocardial } \\
\text { infarction }\end{array}$ & $\begin{array}{l}\text { Effective pacing achieved. } \\
\text { Successful pulmonary } \\
\text { embolectomy at } 3 \text { weeks. } \\
\text { Discharged at } 2 \text { months }\end{array}$ \\
\hline 2 & $\begin{array}{l}\text { Nine episodes of V.F. } \\
\text { preceded by slow nodal } \\
\text { rhythm. No response to } \\
\text { drug therapy. One episode } \\
\text { of transient complete } \\
\text { heart block }\end{array}$ & $\begin{array}{l}\text { Acute myocardial } \\
\text { infarction }\end{array}$ & $\begin{array}{l}\text { Pacing at high rate } \\
\text { prevented recurrence } \\
\text { of V.F. Discharged at } \\
4 \text { weeks }\end{array}$ \\
\hline 3 & $\begin{array}{l}\text { Prolonged ventricular } \\
\text { asystole following DC } \\
\text { shock for recurrent V.F. } \\
\text { Unresponsive to drugs }\end{array}$ & $\begin{array}{l}\text { Acute myocardial } \\
\text { infarction }\end{array}$ & $\begin{array}{l}\text { In spite of successful pacing } \\
\text { and control of V.F., low } \\
\text { cardiac output persisted, } \\
\text { resulting in death within } \\
\text { a few hours }\end{array}$ \\
\hline 4 & $\begin{array}{l}\text { Complete heart block. } \\
\text { Recurrent attacks of } \\
\text { ventricular asystole }\end{array}$ & $\begin{array}{l}\text { Acute myocardial } \\
\text { infarction }\end{array}$ & $\begin{array}{l}\text { Died of cardiogenic shock } \\
\text { despite satisfactory pacing }\end{array}$ \\
\hline 5 & $\begin{array}{l}\text { Complete heart block. } \\
\text { Recurrent attacks of } \\
\text { ventricular asystole }\end{array}$ & $\begin{array}{l}\text { Acute myocardial } \\
\text { infarction }\end{array}$ & $\begin{array}{l}\text { Died of cardiogenic shock } \\
\text { despite satisfactory pacing }\end{array}$ \\
\hline 6 & $\begin{array}{l}\text { Complete heart block. } \\
\text { Recurrent attacks of } \\
\text { ventricular asystole. } \\
\text { Also had several episodes } \\
\text { of V.F. prior to } \\
\text { development of block }\end{array}$ & $\begin{array}{l}\text { Acute myocardial } \\
\text { infarction }\end{array}$ & $\begin{array}{l}\text { Died of heart failure } \\
24 \mathrm{hr} \text { later in spite of } \\
\text { satisfactory pacing }\end{array}$ \\
\hline 7 & $\begin{array}{l}\text { Recurrent ventricular } \\
\text { asystole due to heart } \\
\text { block during } \\
\text { tracheostomy }\end{array}$ & $\begin{array}{l}\text { Severe hypoxia due } \\
\text { to neoplastic } \\
\text { obstruction of the } \\
\text { pharynx }\end{array}$ & $\begin{array}{l}\text { Uneventful post-operative } \\
\text { period and discharged at } \\
8 \text { weeks }\end{array}$ \\
\hline 8 & $\begin{array}{l}\text { Complete heart block. } \\
\text { Ventricular asystole. Also } \\
\text { had several episodes of V.F. } \\
\text { prior to development } \\
\text { of heart block }\end{array}$ & $\begin{array}{l}\text { Acute myocardial } \\
\text { infarction }\end{array}$ & $\begin{array}{l}\text { Three days later V.F. } \\
\text { recurred, resulting in } \\
\text { death. Necropsy showed } \\
\text { recent extension of } \\
\text { infarct }\end{array}$ \\
\hline 9 & $\begin{array}{l}\text { Atrial and ventricular } \\
\text { asystole }\end{array}$ & $\begin{array}{l}\text { Acute myocardial } \\
\text { infarction }\end{array}$ & $\begin{array}{l}\text { Position of the electrode } \\
\text { tip could not be ascertained } \\
\text { due to complete absence } \\
\text { of electrical activity }\end{array}$ \\
\hline 10 & $\begin{array}{l}\text { Ventricular asystole. } \\
\text { Complete heart block }\end{array}$ & $\begin{array}{l}\text { Acute myocardial } \\
\text { infarction }\end{array}$ & $\begin{array}{l}\text { No cardiac output despite } \\
\text { satisfactory pacing. Died }\end{array}$ \\
\hline 11 & $\begin{array}{l}\text { Ventricular asystole. } \\
\text { Complete heart block }\end{array}$ & $\begin{array}{l}\text { Acute myocardial } \\
\text { infarction }\end{array}$ & $\begin{array}{l}\text { Satisfactory pacing. } \\
\text { Discharged at } 6 \text { weeks }\end{array}$ \\
\hline
\end{tabular}

essential for accurate and stable positioning of the electrode and was used in the majority of our cases; but for temporary endocardial pacing, the cavity electrocardiogram can be used rapidly at the bedside without fluoroscopy, and the risk of moving a critically ill patient can be avoided. With a portable image intensifier the electrode can also be inserted without moving the patient, but such costly apparatus is unlikely to become universally available in the near future. Moreover, during resuscitation from cardiac arrest outside the Coronary Care Unit, much time can be wasted assembling the apparatus and this method of electrode insertion can prove life-saving.
In eleven patients this method was attempted during resuscitation and in ten effective temporary pacing was achieved, four patients surviving to leave the hospital.

In only one patient (No. 9 in Table 2) was the technique unsuccessful; both atrial and ventricular asystole occurred, making it impossible to assess the electrode position.

Although the technique is both rapid and simple and can be acquired easily, familiarity with the cavity patterns of the great vessels and cardiac chambers of the right side is essential (Fig. 3). It is particularly important to recognize the coronary sinus pattern with its biphasic or monophasic peaked 

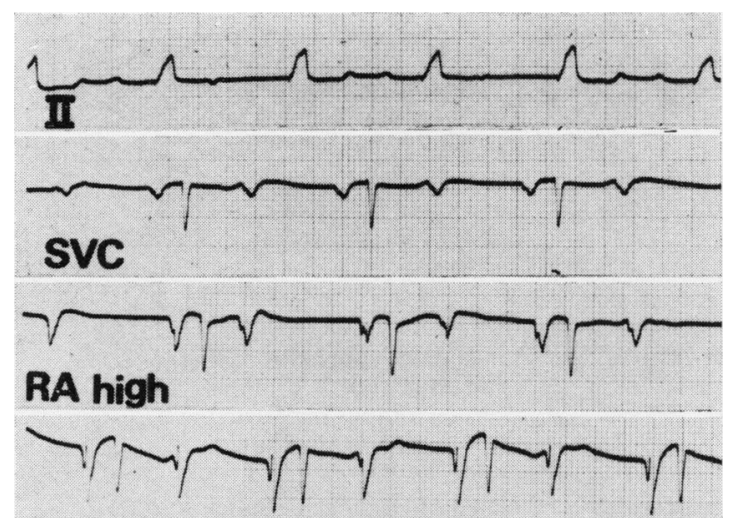

\section{RA low}

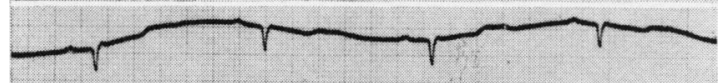

\section{IVC}
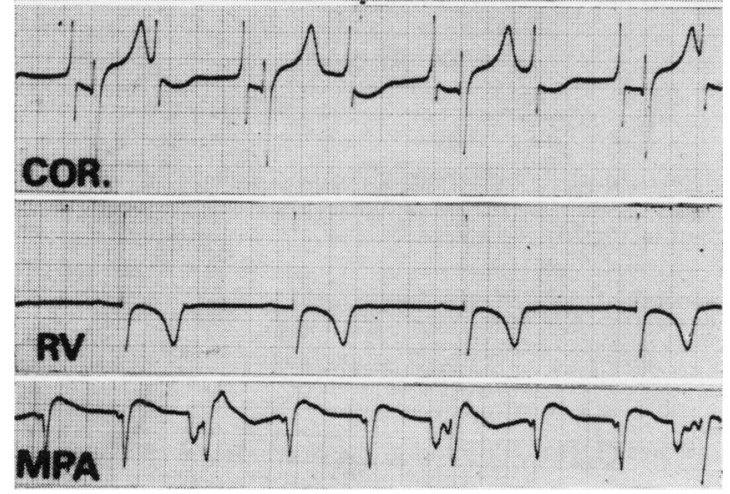

FIG. 3. Cavity ECGs from superior vena cava (SVC), high right atrium (RA high), low right atrium (RA low), inferior vena cava (IVC), coronary sinus (COR.), right ventricle (RV), main pulmonary artery (MPA). The recordings are not simultaneous and standard lead II is shown for comparison.
$P$ waves because its large QRS complexes may otherwise be misinterpreted as an intraventricular record. The initial stimulation threshold in the coronary sinus may be low, but it rises rapidly (Davies \& Sowton, 1966) making it unsuitable for pacing.

In the presence of atrial flutter and fibrillation and slow ventricular rate the $f$ waves are large enough to differentiate between atrial and ventricular cavity patterns. Large flutter waves in an intra-atrial tracing may be mistaken for ventricular tachycardia (Fig. 4) and a simultaneous extracardiac ECG is necessary to avoid this confusion. Contact of the electrode tip with the atrial endocardium causes elevation of the PTa segment and this should not be confused with the ventricular endocardial contact pattern, which shows elevation of the S-T segment (Fig. 5).

Any electrode can be used. Kimball \& Killip (1965) employed Teflon wire and Bay \& Sivertssen (1967) the Elema endocardial electrodes. However, in our experience, U.S.C.I. electrodes have proved to be the most suitable because manipulation is easy and rotation of the patient (Bay \& Sivertssen, 1967) is unnecessary. Although the U.S.C.I. electrodes are rather stiff, increasing the risk of myocardial perforation, in this series there was only one patient in whom this complication occurred, 3 days after electrode insertion. We believe that, with cautious and gentle manipulation of this electrode, the risk of perforation is very small. With a stiffer electrode, the possibility of its forming a 'knot' or becoming entangled in the chordae is much less. A 'knot' formed near the electrode tip in two of the twentysix patients and was probably due to passing too much of the wire too rapidly into the heart before an ECG was taken. Both 'knots' were uncoiled easily, although both required the help of fluoroscopy.

The cavity ECG from different sites in the right ventricle does not vary sufficiently to enable recognition of the exact position of the electrode tip. Thus, in about half of the patients, the electrode tip was found on X-ray to be in the outflow tract instead of the optimal site at the apex, and this may have

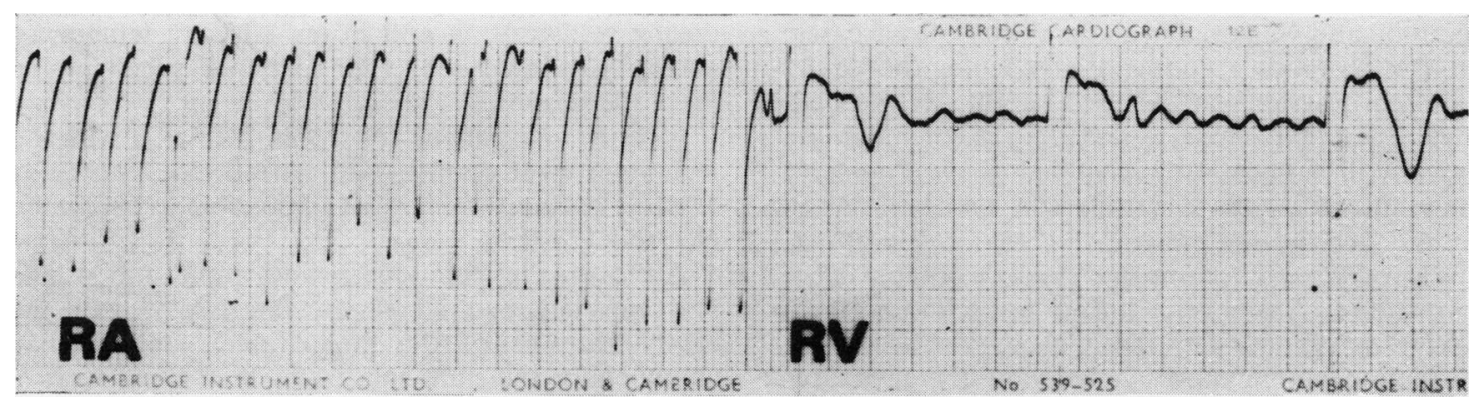

FIG. 4. Cavity ECG from right atrium and right ventricle in atrial flutter. 

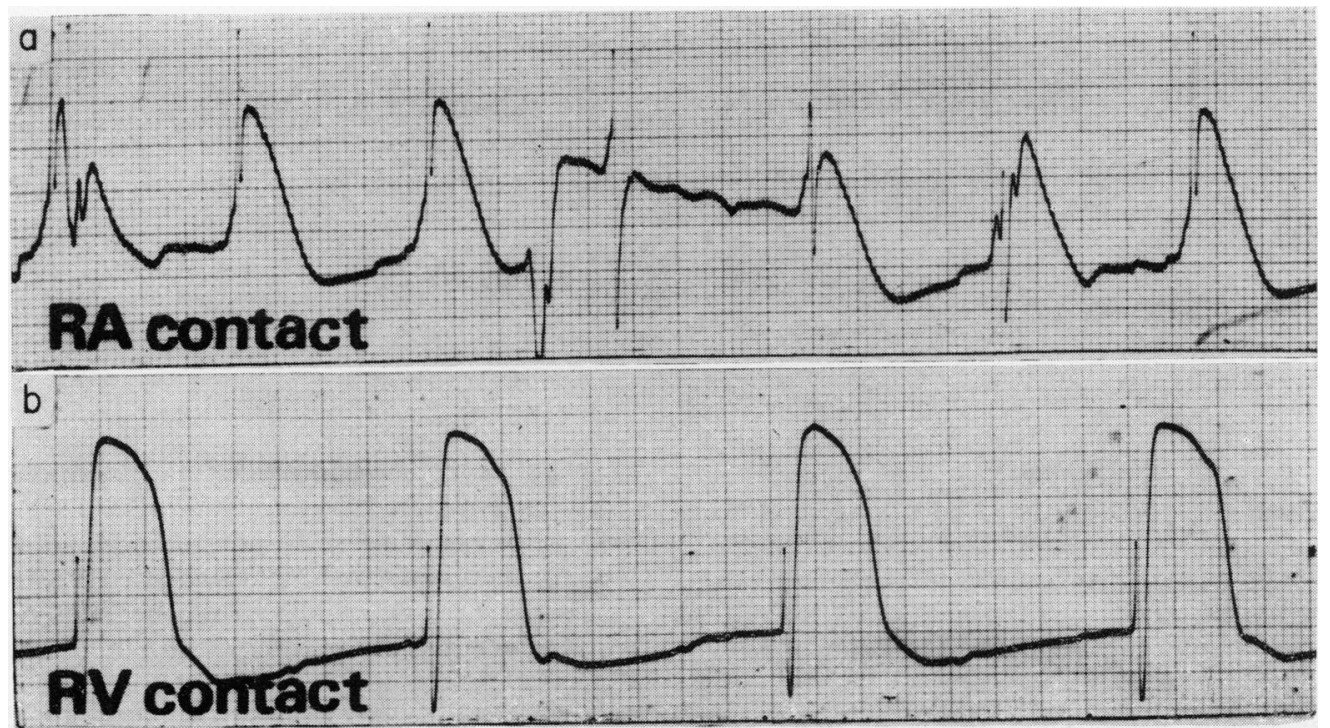

FIG. 5. (a) Cavity ECG from right atrium, showing intermittent contact pattern with raised PTa segments. The patient is in complete heart block and only one idioventricular complex is seen. (b) Cavity ECG from right ventricle showing contact pattern with raised ST segments.

been the cause of the high incidence of electrode displacement $(25 \%)$.

For emergency pacing, we prefer to use arm veins because dissection of cephalic or external jugular veins may be time consuming, and during resuscitation, external massage may prevent the use of the subclavian vein, and anaesthetic apparatus may obstruct the approach to the external jugular vein.

Mechanically induced ventricular ectopics were often observed when the electrode tip crossed the tricuspid valve, but ventricular fibrillation occurred in only one patient (Fig. 2): Dalle (1967) noted a higher incidence and a DC defibrillator should always be available. The patient should be earthed during the procedure and if not a battery powered electrocardiograph should be used for monitoring the cavity ECG to avoid danger of potentials leaking to the electrode and causing ventricular fibrillation.

\section{Acknowledgments}

We wish to thank Dr Aubrey Leatham and Mr Harold Siddons for their help in the preparation of this paper, and also Miss Lynn Morris for technical assistance and Mrs Olivia Myers for secretarial help.

\section{References}

BAy, G. \& SivertSSEN, E. (1967) Intracardiac pacing as emergency treatment in Adams-Stokes syndrome. Brit. med. J. 2, 199.

Dalle, X. (1967) Proceedings of Conference on Cardiac Pacing and Cardioversion. Philadelphia.

Davies, G. \& Sowton, E. (1966) Electrical threshold of the human heart. Brit. Heart J. 28, 231.

Harris, C.W., Hurlburt, J.C., Floyd, W.L. \& Orgain, E.S. (1965) Percutaneous technique for cardiac pacing with a platinum tipped electrode catheter. Amer. J. Cardiol. 15, 48.

Kimball, J.T. \& Killip, T. (1965) A simple bedside method for transvenous intracardiac pacing. Amer. Heart $J$. 70,35 . 